Diabetologia 11, 201--206 (1975)

(C) by Springer-Verlag 1975

\title{
Human C-Peptide in Normal and Diabetic Subjects
}

\author{
L. G. Heding and S. Munkgaard Rasmussen \\ Novo Research Institute and Hvidøre Hospital, Copenhagen, Denmark \\ Received: September 16, 1974, and in revised form: March 17, 1975
}

\begin{abstract}
Summary. Concentrations of human C-peptide, IRI (immunoreactive insulin) and glucose were determined during oral glucose tolerance test $(1.75 \mathrm{~g}$ glucose $/ \mathrm{kg}$ ideal body weight) in 14 normal persons (N), 9 maturity-onset diabetics (DI) and 10 insulin-requiring diabetics (DII) never treated with insulin and in 3 formerly insulin treated diabetics. The mean fasting levels of C-peptide and IRI in the first three groups were: $\mathrm{N}: 0.37 \pm 0.02 \mathrm{nM}$ and $0.048 \pm 0.009 \mathrm{nM}, \mathrm{DI}$ : $0.86 \pm 0.17 \mathrm{nM}$ and $0.11 \pm 0.029 \mathrm{nM}$, DII: $0.37 \pm 0.04 \mathrm{nM}$ and $0.063 \pm 0.009 \mathrm{nM}$. One hour after oral glucose ingestion, the respective values increased to: $\mathrm{N}: 2.53 \pm 0.20 \mathrm{nM}$ and $0.52 \pm$ $0.077 \mathrm{nM}$, DI: $2.49 \pm 0.31 \mathrm{nM}$ and $0.49 \pm 0.11 \mathrm{nM}$, DII: $0.49 \pm 0.05 \mathrm{nM}$ and $0.11 \pm 0.014 \mathrm{nM}$. Although secreted from the pancreas in equimolar concentrations, the molar ratio of C-peptide to insulin in peripheral blood was about 7 in the fasting state, falling to about 5 in the glucose stimulated condition. Maturity-onset diabetics had higher fasting levels of
\end{abstract}

C-peptide than normal subjects, in agreement with the IRI levels. Three patients previously treated with insulin and having insulin antibodies showed $\mathrm{C}$-peptide responses significantly below the normal range. In one of these patients, the test was repeated 9 months later when the insulin antibodies had disappeared, and the C-peptide response observed at that time was much higher. It is suggested that insulin antibodies cause an impaired IRI - and consequently C-peptide response - by constantly removing insulin from the granules in the B-cell. In normal humans the peripheral C-peptide responses to the oral glucose load showed less relative variation than do the insulin responses. Therefore, a radioimmunoassay for C-peptide in addition to the assay for insulin will provide supplementary information on insulin secretion.

Key words: Human C-peptide, insulin, oral glucose tolerance, diabetes.
It has been shown that insulin and C-peptide are present in the pancreas in equimolar concentrations [9]. After stimulation with intravenous glucagon in a pig the two substances were secreted from the Bcells in equimolar concentrations into vena pancreatica duodenale [9]. The liver removes a portion of the IRI, while C-peptide was not taken up by the perfused rat liver [15]. In addition to this, the total metabolic clearance rate of bovine C-peptide was found to be much lower than that of bovine insulin [10]. Equimolar concentrations of C-peptide and insulin in serum were originally reported by Rubenstein and coworkers $[11,13]$, in contrast to the findings of other groups $[14,15]$. But recently, Rubenstein and coworkers found that human C-peptide was present in the peripheral blood in a much higher molar concentration than IRI [1] and the same was reported by Heding et al. [9].

As pointed out by Block et al. $[1,2,3]$, determination of human $\mathrm{C}$-peptide can be most useful for the evaluation of the B-cell secretion in insulin-requiring diabetic patients. But also in normal humans, as well as in a series of conditions with altered insulin sensitivity (e.g. pregnancy), the C-peptide assay may provide information on the insulin secretion over and above the information one can derive from the assay of insulin, mainly because the C-peptide is not taken up by the liver, provided the metabolism of C-peptide remains comparable in the various conditions.

The purpose of this investigation was to determine the concentration of IRI and C-peptide in normals, maturity-onset diabetics (DI) and insulin-requiring diabetics (DII) never on insulin, and in a few diabetics formerly treated with insulin.

\section{Materials and Method}

Human C-peptide was determined using guineapig anti-human proinsulin serum, synthetic human C-peptide as the standard and ${ }^{125} \mathrm{I}-\mathrm{Tyr}$-human-Cpeptide as the tracer, as described by [9] but modified according to [6]. The radioimmunoassay for human C-peptide can be summarized as follows: Insulin + proinsulin and other insulin immunoreactive substances (in $1 \mathrm{ml}$ of serum) were bound to insulin-antibodies coupled to Sepharose. After centrifugation, Cpeptide was determined in the supernatant without interference from other C-peptide-containing substances, such as proinsulin. The standards contained $0.05-1 \mathrm{pmole} / \mathrm{ml}$, the antiserum used (M 1017) had a final dilution of $(1: 2400)$ and ${ }^{125} \mathrm{I}-\mathrm{Tyr}-\mathrm{human} \mathrm{C}$ peptide was added in a concentration of $2 \mathrm{ng} / \mathrm{ml}$. The detection limit $=2$ SD from zero was about 0.003 
pmole in $100 \mu \mathrm{l}$ and the sensitivity in the range of $0-0.3$ was also about $0.03 \mathrm{pmole} / \mathrm{ml}$. Serum presumed not to contain C-peptide (long-term insulin treated juvenile diabetics) gave a slight displacement of the tracer, corresponding to $0.03-0.07 \mathrm{pmole} / \mathrm{ml}$ and hence only values above $0.07 \mathrm{pmole} / \mathrm{ml}$ were regarded as positive. The same serum was analyzed in 30 different assays with the following results: $0.91 \pm 0.07 \mathrm{pmole} / \mathrm{ml}$ (mean $\pm 1 \mathrm{SD}$ ). As no natural intact human C-peptide was available a series of dilutions from a C-peptide-rich waste product were analyzed. A dilution pattern slightly different to that of the synthetic standard was established, which could be due to the presence of fragments. However, the identity of a pure natural standard with a synthetic one remains to be shown. IRI and total extractable IRI in serum with endogenous insulin antibodies were determined according to [7], and the analysis of the same serum in 50 different assays showed $23 \pm 2 \mu \mathrm{U} /$ $\mathrm{ml}$ (mean $\pm 1 \mathrm{SD}$ ). Venous blood glucose was determined using a glucose oxidase method. The oral glucose tolerance tests (OGTT) were performed at the Hvidøre Diabetes Hospital in the following manner: After an overnight fast, a catheter was placed in the antecubital vein of the trial subject, who then ingested a cold solution of glucose containing $1.75 \mathrm{~g}$ of glucose per $\mathrm{kg}$ ideal body weight. Blood was collected at $-30,-5,15,30,45,60,75,90,120$ and $180 \mathrm{~min}$ after administration of glucose, allowed to stand at $4^{\circ} \mathrm{C}$ for at least one hour and then centrifuged. The before and during the test. Group DI, maturity-onset diabetics, comprised the remaining diabetic subjects [8]. It has been shown that all diabetics whose serum insulin remained below $30 \mu \mathrm{U} / \mathrm{ml}$ during two oral glucose tolerance tests needed insulin whereas the remaining patients could be controlled on diet and oral antidiabetic agents. Table 1 shows the age, sex, duration of diabetes, and weight index ${ }^{1}$ of the 14 normals and diabetics, as well as the amount of glucose excreted in urine during the OGTT. Supplementary data on the three insulin treated patients (Tables 1 and 4) are as follows: JST (aged 18 years) was diagnosed as juvenile type diabetic with classical symptoms three months prior to the OGTT as shown in Table 4, at which time insulin treatment was instituted. Three months later, on admission to the Hvidøre Diabetes Hospital, he received 48 i.U. NPH daily but this dose could be gradually reduced to 0 and his diabetes satisfactorily controlled on diet. Although treatment with a conventional pork insulin preparation had lasted for only 3 months, the patient had developed insulin antibodies. The OGTT was performed 4 days after the last insulin injection. GMJ developed diabetes at the age of 47 ; the first symptom was precoma; no provocative infection or any other cause could be demonstrated. He was treated with 36 i.U. NPH daily for about 9 years, whereupon the insulin treatment was suspended and his diabetes controlled with diet. The OGTT was performed 5 days after the last insulin injection. This patient, too, had

Table 1. Sex, weight index, age, duration of diabetes and excretion of glucose during OGTT in normal subjects and diabetic patients

\begin{tabular}{|c|c|c|c|c|c|c|c|c|c|c|}
\hline \multirow[t]{3}{*}{ Group } & \multirow[t]{3}{*}{$\operatorname{sex}$} & \multirow{3}{*}{$\begin{array}{l}\text { number } \\
\text { of } \\
\text { patients }\end{array}$} & \multicolumn{2}{|c|}{ weight index } & \multicolumn{2}{|l|}{ age } & \multirow{2}{*}{\multicolumn{2}{|c|}{$\begin{array}{l}\text { excretion of glucose in } \\
\text {-urine during OGTT (g) }\end{array}$}} & \multirow{2}{*}{\multicolumn{2}{|c|}{$\begin{array}{l}\text { duration of diabetes } \\
\text { years }\end{array}$}} \\
\hline & & & range & mean & range & mean & & & & \\
\hline & & & & & & & range & mean & range & mean \\
\hline$\overline{\mathrm{N}}$ & $\mathrm{f}$ & $\begin{array}{l}8 \\
6\end{array}$ & $0.98-1.17$ & 1.04 & $\begin{array}{l}23-53 \\
15-65\end{array}$ & $\begin{array}{l}37 \\
34\end{array}$ & $\begin{array}{l}0-1 \\
0-2\end{array}$ & 0.12 & - & - \\
\hline DI & $\begin{array}{l}\mathrm{m} \\
\mathrm{f} \\
\mathrm{m}\end{array}$ & $\begin{array}{l}0 \\
3 \\
6\end{array}$ & $\begin{array}{l}0.80-1.23 \\
0.90-1.51 \\
0.89-1.61\end{array}$ & $\begin{array}{l}1.00 \\
1.18 \\
1.16\end{array}$ & $\begin{array}{l}25-61 \\
24-72\end{array}$ & $\begin{array}{l}34 \\
45 \\
47\end{array}$ & $\begin{array}{l}0-2 \\
0-9 \\
0-24\end{array}$ & $\begin{array}{l}0.53 \\
3.70 \\
6.00\end{array}$ & $\begin{array}{l}0-0.5 \\
0.1-6\end{array}$ & $\begin{array}{l}- \\
0.2 \\
1.4\end{array}$ \\
\hline DII & $\begin{array}{l}\mathrm{f} \\
\mathrm{m}\end{array}$ & $\begin{array}{l}2 \\
8\end{array}$ & $\begin{array}{l}0.97 \\
0.89-1.09\end{array}$ & $\begin{array}{l}0.97 \\
0.96\end{array}$ & $\begin{array}{l}17 \\
19-70\end{array}$ & $\begin{array}{l}17 \\
40\end{array}$ & $\begin{array}{l}19-22 \\
12-44\end{array}$ & $\begin{array}{l}20.5 \\
30.4\end{array}$ & $\begin{array}{l}0 \\
0-16\end{array}$ & $\begin{array}{l}0 \\
2.4\end{array}$ \\
\hline $\begin{array}{l}\text { diabetics } \\
\text { formerly } \\
\text { on insulin }\end{array}$ & $\mathrm{m}$ & 3 & $0.91-1.21$ & 1.09 & $18-59$ & 38 & $0-3$ & 1 & $0.3-9$ & 3.8 \\
\hline
\end{tabular}

a time from diagnosis of diabetes until performance of OGTT

serum was pipetted into plastic tubes and stored at $-18^{\circ} \mathrm{C}$ until used. There were altogether 19 diabetics who had never previously received insulin and three who had. The 19 previously untreated diabetics were divided into two groups. Group DII, insulin requiring diabetics, had IRI values below $30 \mu \mathrm{U} / \mathrm{ml}$ insulin antibodies. In the case of JLP, diabetes was diagnosed when he was 34 years of age, after approximately one year of symptoms such as loss of weight, which was remarkable inasmuch as the had been

\footnotetext{
1 body weight divided by the ideal body weight according to life insurance tables
} 
obese since childhood. He was treated with 24 i.U. of Lente daily for about 2 years, whereupon the insulin treatment was replaced by diet. The first OGTT was performed a few days, the second OGTT 9 months after the suspension of the insulin treatment. This patient had no detectable insulin antibodies at the time of the second test.

\section{Results}

Fig. 1, 2 and 3 show glucose, IRI and C-peptide in Groups N, DI and DII. In all three groups, the fasting as well as the stimulated levels of C-peptide were higher than those of insulin. The fasting levels of C-peptide were nearly the same in N and DII, whereas this level was higher in DI.

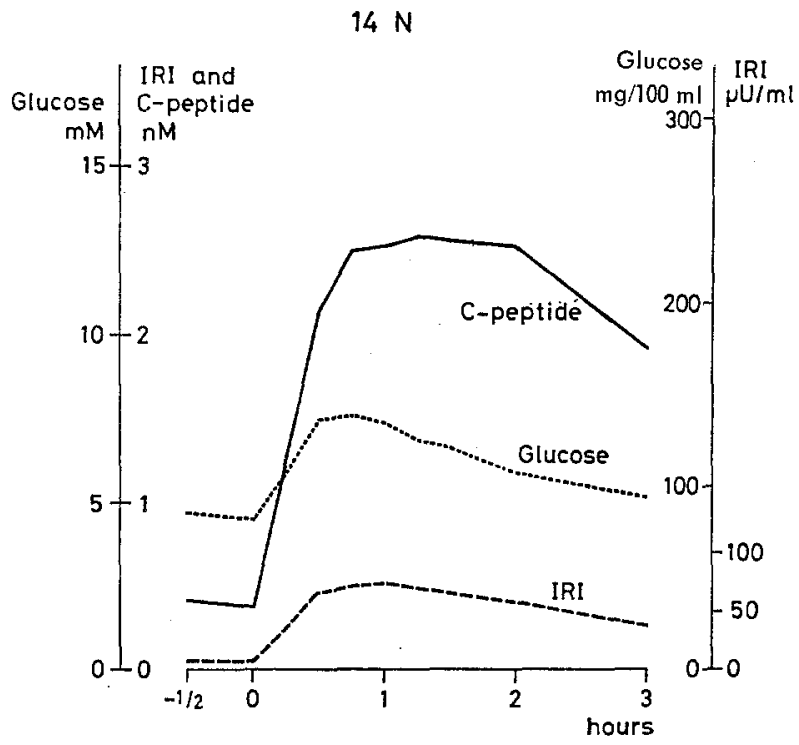

Fig. 1. Blood glucose, serum IRI and C-peptide concentrations in 14 normal persons after OGTT $(1.75 \mathrm{~g}$ glucose per $\mathrm{kg}$ ideal body weight)

Table 2 shows the mean values of glucose, IRI and C-peptide in the three groups at $-5 \mathrm{~min}$ and at 1,2 and $3 \mathrm{~h}$ after glucose. The SD expressed in $\%$ of the mean values was - especially in the normal group - smaller for C-peptide than the corresponding value of IRI.

The mean molar ratio of C-peptide to IRI at the various times of testing is shown in Table 3 . The ratio in the fasting state is considered to be the least accurate one inasmuch as it is calculated using two low concentrations, and the mean values are shown in parentheses. The molar ratio of $\mathrm{C}$-peptide to insulin decreased in all three groups after stimulation, it in-

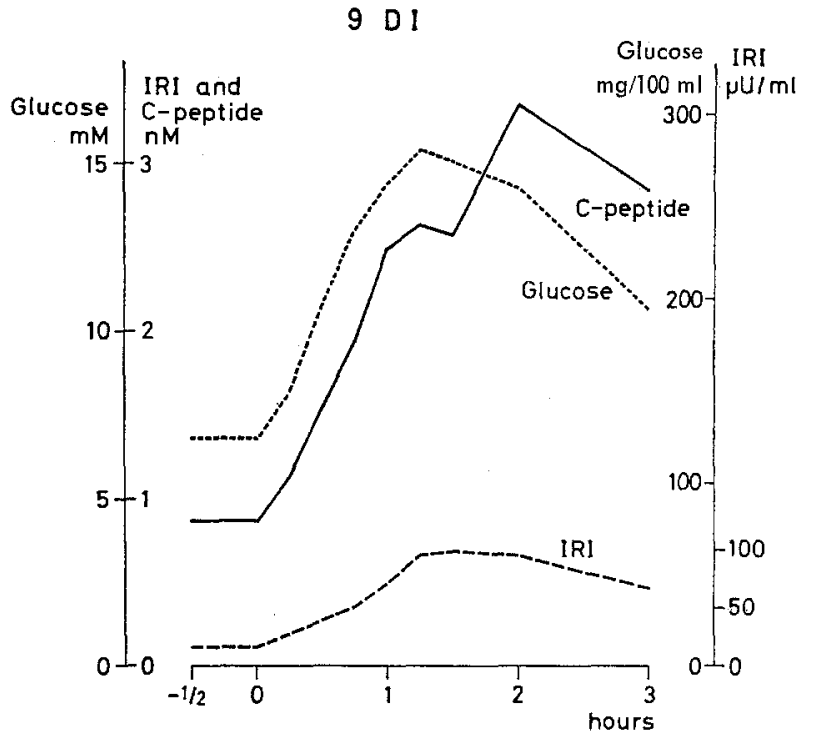

Fig. 2. Post OGTT blood glucose, serum IRI and C-peptide concentrations in 9 maturity-onset-type diabetic patients never treated with insulin $(1.75 \mathrm{~g}$ glucose per $\mathrm{kg}$ ideal body weight)

$10 \mathrm{D} \mathrm{II}$

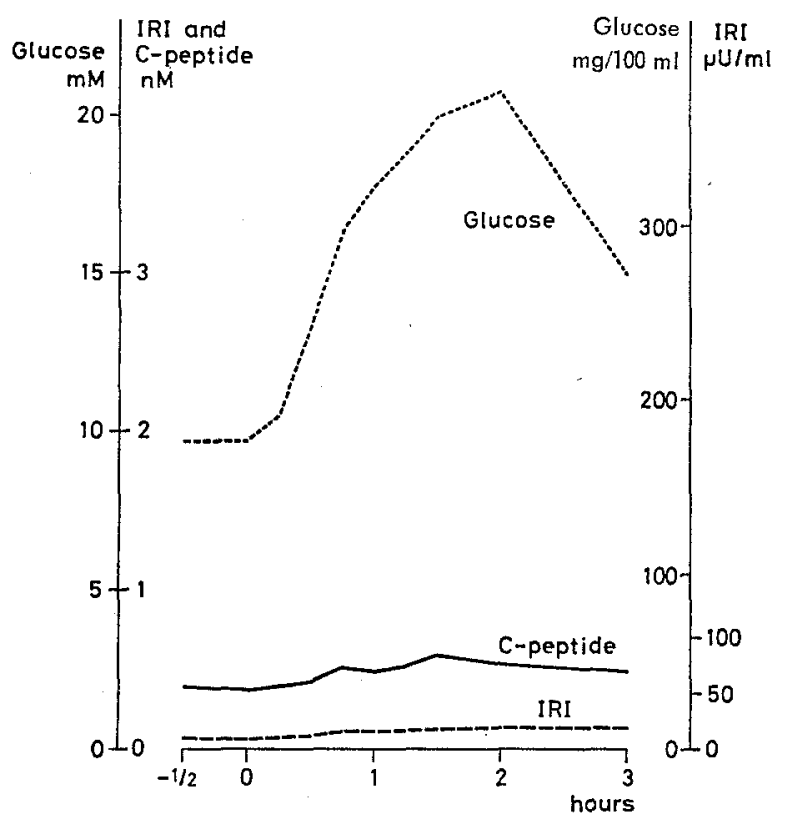

Fig. 3. Post OGTT blood glucose, serum IRI and C-peptide concentrations in 10 insulin-requiring diabetic patients never treated with insulin ( $1.75 \mathrm{~g}$ glucose per $\mathrm{kg}$ ideal body weight)

creased again in the $\mathrm{N}$ and DI groups 2 hrs after glucose, simultaneously with a decrease in the IRI values. This was not the case in the DII group, where the IRI values were at maximum after 2 and 3 hrs.

The results of OGTT in the 3 formerly insulintreated diabetic patients are shown in Table 4 . In the 
Table 2. Post OGTT variations in blood glucose, serum IRI and C-peptide in normal persons and diabetic patients (1.75 $g$ glucose $(\mathrm{kg}$ ideal body weight)

\begin{tabular}{|c|c|c|c|c|c|c|c|c|c|c|}
\hline \multirow{2}{*}{$\begin{array}{l}\text { Test } \\
\text { group }\end{array}$} & \multirow[t]{2}{*}{ time } & \multicolumn{3}{|c|}{ glucose $\mathrm{mM}$} & \multicolumn{3}{|c|}{ IRI nM } & \multicolumn{3}{|c|}{ C-peptide, nM } \\
\hline & & mean & $\mathrm{SD}$ & $\begin{array}{l}\text { Coefficient } \\
\text { of } \\
\text { variation }\end{array}$ & mean & $\mathrm{SD}$ & $\begin{array}{l}\text { Coefficient } \\
\text { of } \\
\text { variation }\end{array}$ & mean & SD & $\begin{array}{l}\text { Coefficient } \\
\text { of } \\
\text { variation }\end{array}$ \\
\hline \multirow[t]{4}{*}{$N \quad$ (14) } & $-5 \min$ & 4.5 & 0.30 & 6.7 & 0.048 & 0.033 & 68.7 & 0.37 & 0.071 & 19.2 \\
\hline & $1 \mathrm{~h}$ & 7.4 & 1.86 & 25.1 & 0.52 & 0.29 & 55.8 & 2.53 & 0.70 & 27.6 \\
\hline & $2 \mathrm{~h}$ & 5.9 & 1.34 & 22.7 & 0.40 & 0.22 & 55.0 & 2.54 & 0.71 & 27.9 \\
\hline & $3 \mathrm{~h}$ & 5.2 & 1.37 & 26.4 & 0.26 & 0.12 & 46.2 & 1.93 & 0.62 & 32.1 \\
\hline \multirow{4}{*}{ DI (9) } & $-5 \min$ & 6.8 & 2.1 & 30.9 & 0.11 & 0.088 & 80.0 & 0.86 & 0.51 & 59.4 \\
\hline & $1 \mathrm{~h}$ & 14.4 & 3.0 & 20.8 & 0.49 & 0.32 & 65.4 & 2.49 & 0.93 & 37.4 \\
\hline & $2 \mathrm{~h}$ & 14.3 & 5.7 & 40.0 & 0.67 & 0.57 & 85.0 & 3.36 & 1,70 & 50.6 \\
\hline & $3 \mathrm{~h}$ & 10.7 & 5.2 & 48.7 & 0.47 & 0.29 & 72.5 & 2.84 & 0.96 & 33.7 \\
\hline \multirow[t]{4}{*}{ DII (10) } & $-5 \min$ & 9.7 & 2.1 & 21.6 & 0.063 & 0.027 & 43.0 & 0.37 & 0.14 & 37.8 \\
\hline & $1 \mathrm{~h}$ & 17.8 & 2.6 & 14.6 & 0.105 & 0.042 & 40.0 & 0.49 & 0.17 & 34.7 \\
\hline & $2 \mathrm{~h}$ & 20.8 & 3.0 & 14.4 & 0.13 & 0.042 & 32.3 & 0.54 & 0.19 & 35.2 \\
\hline & $3 \mathrm{~h}$ & 15.0 & 4.0 & 26.7 & 0.13 & 0.050 & 38.4 & 0.49 & 0.17 & 34.8 \\
\hline
\end{tabular}

Table 3. Mean molar ratio of C-peptide to IRI in normal persons and diabetic patients in fasting condition and after OGTT ( $1.75 \mathrm{~g}$ glucose per $\mathrm{kg}$ ideal body weight)

\begin{tabular}{|c|c|c|c|c|c|c|c|c|c|}
\hline \multirow[b]{2}{*}{ Test group } & \multicolumn{9}{|c|}{ time in $\mathrm{min} / \mathrm{hrs}$} \\
\hline & $\overline{-5}$ & 15 & 30 & 45 & 60 & 75 & 90 & $2 \mathrm{~h}$ & $\overline{3 h}$ \\
\hline $\mathrm{N} \quad$ (14) & $(7.7)^{\mathrm{a}}$ & 5.4 & 4.7 & 5.0 & 4.9 & 5.3 & 5.6 & 6.4 & 7.4 \\
\hline DI (9) & $(7.8)^{\mathrm{a}}$ & 6.0 & 5.8 & 5.6 & 5.1 & 4.0 & 3.8 & 5.1 & 6.0 \\
\hline DII (10) & $(5.9)^{\mathrm{a}}$ & 5.6 & 5.9 & 4.9 & 4.7 & 4.7 & 4.9 & 4.2 & 3.8 \\
\hline
\end{tabular}

${ }^{2}$ less accurate, as both C-peptide and IRI were low values

Table 4. Blood glucose, serum IRI and C-peptide in 3 diabetic patients formerly treated with insulin for varying periods of time

\begin{tabular}{|c|c|c|c|c|c|c|c|c|c|c|c|}
\hline \multirow{3}{*}{$\begin{array}{l}\text { Init. } \\
\text { and } \\
\text { age }\end{array}$} & \multirow{3}{*}{$\begin{array}{l}\text { substance } \\
\text { measured }\end{array}$} & \multicolumn{9}{|l|}{ time } & \multirow[b]{3}{*}{3} \\
\hline & & \multicolumn{2}{|c|}{$\overline{\text { in } \min }$} & \multicolumn{7}{|c|}{ in $\mathrm{hrs}$} & \\
\hline & & -30 & -5 & $\overline{1 / 4}$ & $1 / 2$ & $3 / 4$ & 1 & $11 / 4$ & $11 / 2$ & 2 & \\
\hline JST & glucose $\mathrm{mM}$ & 4.6 & 4.6 & 6.0 & 10.3 & 12.6 & 13.7 & 12.1 & 11.0 & 11.4 & 7.4 \\
\hline \multirow[t]{2}{*}{18} & total IRI $\mathrm{nM}$ & 1.57 & 1.41 & 1.57 & 1.65 & 2.00 & 1.88 & 1.81 & 1.88 & 1.94 & 1.82 \\
\hline & C-peptide nM & 0.19 & 0.22 & 0.21 & 0.36 & 0.35 & 0.31 & 0.34 & 0.34 & 0.33 & 0.37 \\
\hline GJM & glucose $\mathrm{mM}$ & 6.1 & 6.0 & 7.9 & 10.5 & 12.2 & 13.8 & 13.9 & 14.9 & 12.5 & 7.3 \\
\hline \multirow[t]{2}{*}{59} & total IRI $\mathrm{nM}$ & 0.13 & 0.11 & 0.57 & 0.21 & 0.28 & 0.32 & 0.44 & 0.53 & 0.63 & 0.53 \\
\hline & C-peptide $\mathrm{nM}$ & 0.22 & 0.16 & 0.35 & 0.40 & 0.45 & 0.60 & 0.65 & 0.65 & 0.85 & 0.55 \\
\hline $\mathbf{J L P}^{\mathrm{a}}$ & glucose $\mathrm{mM}$ & 4.2 & 4.0 & 4.7 & 6.7 & 8.5 & 8.6 & 9.5 & 9.7 & 9.4 & 6.9 \\
\hline \multirow[t]{2}{*}{36} & total IRI $\mathrm{nM}$ & 1.20 & 1.15 & 1.20 & 1.45 & 1.90 & 1.41 & 1.70 & 1.70 & 1.70 & - \\
\hline & C-peptide nM & - & - & 0.30 & - & - & - & 0.40 & - & 0.24 & - \\
\hline $\mathbf{J L P}^{b}$ & glucose $\mathrm{mM}$ & 5.5 & 5.5 & 5.3 & 8.2 & 10.0 & 10.5 & 11.6 & 11.8 & 7.4 & 5.5 \\
\hline \multirow[t]{2}{*}{36} & IRI $\quad \mathrm{nM}$ & 0.11 & 0.11 & 0.09 & 0.17 & 0.25 & 0.28 & 0.34 & 0.45 & 0.39 & 0.40 \\
\hline & C-peptide nM & - & 0.53 & 0.54 & 1.55 & 1.85 & 1.80 & - & - & 2.20 & 2.05 \\
\hline
\end{tabular}

a This OGTT was performed 3 days after suspension of insulin treatment

b This OGTT was performed 9 months after suspension of insulin treatment insulin antibodies were no longer detectable

presence of antibodies, total IRI was determined after extraction. These three patients showed maximum increases in total IRI: from 1.4 to $2.0 \mathrm{nM}$ (an increase of approx. $85 \mu \mathrm{U} / \mathrm{ml}$ ), from 0.11 to $0.63 \mathrm{nM}$ (an increase of approx. $75 \mu \mathrm{U} / \mathrm{ml}$ ) and from 1.2 to $1.9 \mathrm{nM}$ (an increase of approx. $90 \mu \mathrm{U} / \mathrm{ml}$ ), whereas their C-peptide increments were subnormal. The glucose curve was abnormal in all three cases.

\section{Discussion}

Since proinsulin, the intermediates and insulin were removed prior to $\mathrm{C}$-peptide determination, the values recorded are a measure of the circulating intact C-peptide and, possibly, of an immunoreactive product of its degradation, e.g., the chymotryptic fragment $[1-24]$ found in pancreatic extracts [9]. 
The mean C-peptide concentration in 14 fasting normal subjects was $0.37 \pm 0.02 \mathrm{nM}$, or $1.11 \pm 0.06$ $\mathrm{ng} / \mathrm{ml}$, which is in good agreement with the $1.3 \pm 0.3$ $\mathrm{ng} / \mathrm{ml}$ for total CPR (C-peptide immunoreactivity) found in 9 normal persons by Block et al. [1]. One hour after glucose $(1.75 \mathrm{~g} / \mathrm{kg})$, the concentration was $2.53 \pm 0.20 \mathrm{nM}$, or $7.59 \pm 0.6 \mathrm{ng} / \mathrm{ml}$. This is higher than the value reported by Block et al. [1] one hour after a similar glucose load. The reason for this difference may be of methodological nature, considering the differences in the standard and the antisera used.

The antiserum (M 1017) used in this study records a small but significant value in sera from long-term insulin-treated juvenile diabetics deprived of B-cell function [6]. Furthermore, dilution of sera containing $>0.5 \mathrm{nM}$ C-peptide caused in some cases a certain dilution effect (higher dilution gave higher values), indicating differences between the standard and the substance(s) measured. Therefore, the use of different dilutions of sera with a high content of C-peptide in the two studies could have been contributory to the difference in the mean values recorded.

The maturity-onset-type diabetics (DI) showed increased fasting C-peptide (and IRI) levels in comparison with the normal group and the mean value of $0.86 \pm 0.17 \mathrm{nM}$, or $2.58 \pm 0.51 \mathrm{ng} / \mathrm{ml}$, is very close to the mean of $2.7 \pm 0.7 \mathrm{ng} / \mathrm{ml}$ as reported by Block et al. for a group of insulin-treated adult-onset diabetics. The post glucose values do not agree $(10.08$ $\mathrm{ng} / \mathrm{ml} \pm 1.68$ in our DI group vs. $5.0 \pm 1.1 \mathrm{ng} / \mathrm{ml}$ $2 \mathrm{hrs}$ after glucose in the patients studied by Block et al.), but then the two groups are not comparable because the patients reported on by Block et al. had been treated with insulin for years and, hence, their B-cell activity might have been reduced as compared to our patients, who had never received insulin. Unfortunately, the high total CPR levels measured in the adult-onset diabetics treated with insulin comprised both C-peptide as well as proinsulin, the latter being the major part of the CPR [1], and this renders comparison of C-peptide and CPR invalid. Furthermore, the formation of insulin antibodies in the insulintreated patients may be capable of modifying the insulin + C-peptide responses to glucose. This will be discussed later in the paper. One patient formerly treated with insulin (JLP, OGTT ${ }^{2}$ in Table 4) showed a C-peptide reponse $(2.2 \mathrm{nM}=6.6 \mathrm{ng} / \mathrm{ml}$ at $2 \mathrm{hrs})$ to the oral glucose load that corresponded to the lower part of the range in the DI group. Nevertheless this patient's glucose curve was better than that in the DI group. JLP who then had been without insulin for 9 months no longer had circulating insulin antibodies.

All but one juvenile-type diabetics (DII) reported in this paper had detectable IRI and C-peptide levels in the fasting state, and after glucose stimulation they all showed significant but very low C-peptide and IRI responses. Thus, this group was different from the juvenile diabetics described by Block et al. [1], where the IRI and C-peptide were undetectable.

The mean fasting level of C-peptide in Group DII was normal whereas the mean IRI was slightly (not significantly) elevated. Since this investigation did not comprise the determination of the amount of proinsulin in the samples it cannot be determined at present whether an increased proinsulin concentration was the reason for the decreased C-peptide: IRI ratio in these patients.

As insulin and C-peptide are secreted from the Bcell in equimolar concentrations, a significant correlation is to be expected between the peripheral levels and has, in fact, been reported [1]. However, the two peptides have different metabolic clearance rates, and the molar ratio will vary during unsteady states (see Table 3), rendering this correlation less apparent. The variation between IRI responses in normal persons after glucose is normally high. In this material, the IRI values one hour after glucose were in the range of $0.21-1.21 \mathrm{nM}$, while C-peptide ranged only between 1.7 and $4.0 \mathrm{nM}$. Thus, when C-peptide was used as an indicator of insulin secretion rather than insulin itself, a more uniform pattern was seen in normal persons after similar glucose loads. This could be due, partially, to variations in the uptake of insulin by the liver.

The three patients who had been treated with insulin and had insulin antibodies showed a significant increase in total IRI after glucose. As most of this IRI was bound to antibodies, which made its half-life much longer, the measured increments cannot be compared to those observed in normal persons or in diabetics devoid of insulin antibodies. The increase in C-peptide was surprisingly low in these three patients, resembling Group DII of insulin-requiring diabetics. OGTTs in JLP were performed both immediately after the suspension of insulin therapy as well as 9 months later. Even though only 3 samples were available for $\mathrm{C}$-peptide analysis from the first test, there can be no doubt that the C-peptide response was much higher in the second test. At that time, the patient no longer had insulin antibodies and it seems likely that the antibodies were responsible, at least in part, for the low IRI - and consequently for the low $\mathrm{C}$-peptide response. Thus it has been shown that insulin antibodies reach the B-cell, where they are specifically bound to the granules [4] and cause degranulation $[5,12,16]$. Therefore, the $C$-peptide assay is useful in determining whether or not the B-cells are 
active in insulin-treated diabetics when circulating insulin antibodies are present. However, the B-cell response in the presence of insulin antibodies does not allow conclusions about the B-cell function in the absence of antibodies. Nevertheless, no exogenous insulin was required at the time of the test, and the glucose tolerance was disturbed only moderately, being better than the mean in Group DI. This finding is difficult to interpret, but it should be borne in mind that when insulin is bound to antibodies it is protected from degradation by the liver, and this, in combination with a slow release from the antibody complexes, may result in a more "economical" use of the insulin than in a normal organism. Another possibility is that other hormonal changes, e.g. reduced glucagon secretion, were involved in the improved glucose tolerance.

It has been found [1] that an abnormally high portion of the IRI bound to antibodies in the insulin treated patients was proinsulin. Whether or not this was also the case in the three patients reported here is being investigated.

Acknowledgements. We wish to thank E. Parbst, M. Sc., for performing the insulin determinations, and Miss Marianne Knudsen for her excellent technical assistance.

\section{References}

1. Block, M. B., Mako, M. E., Steiner, D. F.: Rubenstein, A. H.: Circulating C-peptide immunoreactivity. Studies in normals and diabetic patients. Diabetes 21, 1013-1026 (1972)

2. Block, M. B., Mako, M. E., Steiner, D. F., Rubenstein, A. H.: Diabetic ketoacidosis: Evidence for C-peptide and proinsulin secretion following recovery. J. clin. Endocr. 35, $402-406$ (1972)

3. Block, M. B., Rosenfield, R. L., Máko, M. E., Steiner, D. F., Rubenstein, A. H.: Sequential changes in beta-cell function in insulin-treated diabetic patients assessed by C-peptide immunoreactivity. New Engl. J. Med. 288, $1144-1148$ (1973)

4. Blumenthal, D. S., Berns, A. W., Blumenthal, H. T.: Anti- insulin serum effects on islets of Langerhans of chick embryo. Arch. Path. 77, 107-112 (1964)

5. Gregor, W. H., Martin, J. M., Williamson, J. R., Lacy, P. E., Kipnis, D. M.: A study of the diabetic syndrome produced in rats by anti-insulin serum. Diabetes 12, 73-81 (1963)

6. Heding, L. G.: Radioimmunological determination of human C-peptide in serum. Accepted by Diabetologia (1975)

7. Heding, L. G.: Determination of total serum insulin (IRI) in insulin-treated diabetic patients. Diabetologia 8, 260266 (1972)

8. Heding, L. G., Munkgaard Rasmussen, S.: Determination of pancreatic and gut glucagon-like immunoreactivity (GLI) in normal and diabetic subjects. Diabetologia 8, $408-411$ (1972)

9. Heding, L. G., Larsen, U. D., Markussen, J., Jørgensen, K. H., Hallund, O.: Radioimmunoassays for human, pork and ox C-peptides and related substances. Horm. Metab. Res. Suppl. Vol. 5, 40--44 (1974)

10. Katz, A. I., Rubenstein, A. H.: Metabolism of proinsulin, insulin and C-peptide in the rat. J. clin. Invest. 52, 11131121 (1972)

11. Melani, F., Rubenstein, A. H., Oyer, P. E., Steiner, D. F.: Identification of proinsulin and C-peptide in human serum by a specific immunoassay. Proc. nat. Acad. Sci. (Wash.) 67, 148-155 (1970)

12. Morgan, C. R., Carpenter, A. M., Lazarow, A.: Effect of insulin antibodies on pancreatic islet insulin and beta cell granule content. Anat. Rec. 153, 49-54 (1965)

13. Rubenstein, A. H., Block, M. B., Starr, J., Melani, F., Steiner, D. F.: Proinsulin and C-peptide in blood. Diabetes 21, Suppl. 2, 661-672 (1972)

14. Schlichtkrull, J.: Proinsuline et substances apparentées. Path. et Biol. 19, 885-892 (1971)

15. Stoll, R. W., Touber, J. L., Ensinck, J. W., Williams, R. H.: Substances immunologically related to proinsulin or connecting peptide in swine plasma. Horm. Metab. Res. 2, 153-156 (1970)

16. Toreson, W. E., Lee, J. C., Grodsky, G. M.: The histopathology of immune diabetes in the rabbit. Amer. J. Path. 52, 1099-1109 (1968)

\author{
Dr. L. G. Heding \\ Novo-Research Inst. \\ Novo Allé \\ DK-2880 Bagsvaerd \\ Denmark
}

